\title{
In memoriam Professor Michel Combarnous
}

\author{
Received: 4 September 2018 / Accepted: 4 September 2018
}

The announcement of the passing of Michel came as a shock for our community: it is obvious that the scientific and institutional life of Mechanics these past 50 years has been closely linked to him.

Graduate of one of the famous French Grandes Ecoles d'Ingénieurs, Michel was involved during his academic career in a lot of authorities where he often held the position of highest responsibility: - University of Bordeaux, Ecole Polytechnique "X", ENSAM, and ENSPM - INSIS, the scientific department of CNRS devoted to the sciences for the Engineers - the French Academy of Science and Technology - the Ministry of Research and Education Firms Renault, Saint-Gobain, IFP, to name just a few. And he wasn't there just for show! He was one of the most ardent defenders of these "Engineering Sciences", all the while open-minded towards all other sciences, a defender of the bringing-together of academics and industry at a time when this was not self-evident.

From a scientific point of view, the list of all the domains in which he involved himself, is too long to enumerate. I have chosen two in which he was an enlightened forerunner.

Michel was, along with a small group from Paris, Toulouse, Nancy, Bordeaux, the founder of what may be called "The French School of Porous Media" which had an international renown: the theoretical advances and their applications in petroleum engineering, in geology, thermal insulation, and so on, have been major thanks to this group. He was also one of the first to formulate the concepts of a
"General Energetics and Ecology" long before it was politically fashionable to do so: he trained generations of students and there is no doubt they were the heralds and the wise decision-makers in groups such as the COP and the Paris Agreements.

I shall conclude by remembering that Michel Combarnous was also Chairman of our French Mechanics Association, AFM (and thus one of its founding members along with Paul Germain 20 years ago), of which I am today the spokesman. As such Michel was one of the Presidents and then a permanent member of the 'Haut Comité Mécanique' (HCM): he thus contributed to the writing and review of the report on Mechanical Science, Le Livre Blanc de la Mécanique. We only recently held a meeting (Academy/HCM/AFM) on the actualization of this major report, where his quick mind and sense of synthesis shone once more. Moreover, Michel warmly and continuously promoted the Journal "Mechanics \& Industry".

The entire community is therefore sad to see such an outstanding scientist, a brilliant, active and devoted colleague leave us. We will surely miss him. In this difficult moment, our thoughts go to his family for whom we also know that Michel was very close and attentive despite his (hyper) active professional life and his passion for Science.

Michel, we will always remember you.

Professor Eric Arquis President of AFM 